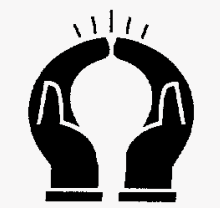

HANDS-OH SOLUTIONS

\section{Energy-Saving Tips for Small Businesses}

HANDS-ON SOLUTIONS TO IMPROVE

YOUR PROFITS AND PRODUCTIVITY

\section{So what's in it for you?}

This flyer provides proven, straightforward, energysaving actions that could save $10 \%$ to $50 \%$ on your energy bills.

If you own your building, energy savings go straight to your bottom line-dollars that you can apply toward your competitive position, your business expansion, or other capital improvements. Even if you rent the building space, you probably pay energy bills.

In either case, you can put your hands on these quick and easy ways to save now.

\section{Remember to use these hands-on ideas}

Don't assume that these measures have been applied in your building. For help, you can contact your local utility, which often provides technical guidance and rebates or other financial incentives for certain energy efficiency measures.

(1) Adjust thermostats. Turn down the building's heating thermostat and turn up its cooling thermostat, especially when the building is not occupied. No Cost.

Reduce the hot water temperature. Reducing the temperature on your water heater thermostat can decrease heat loss from your tank. For washing hands, you may be able to turn the temperature to $110^{\circ} \mathrm{F}\left(43^{\circ} \mathrm{C}\right)$. Dishwashing may require higher temperature settings such as $130^{\circ} \mathrm{F}\left(54^{\circ} \mathrm{C}\right)$. No Cost.

3 Install water flow restrictors and aerators in sink faucets. These measures can save you money by reducing water use (including hot water). Low Cost.

Reduce lighting. Remove lamps where you have more lighting than you really need, but be sure to maintain safe lighting conditions for work areas. Turn lights off when they're not in use. No Cost.

Seal heating and cooling ductwork. Leakage from areas such as joints, elbows, and connections can be substantialas much as $20 \%$ to $30 \%$. This is especially costly if the ducts travel through unheated or uncooled spaces such as attics, basements, or crawl spaces. Use duct tape or caulk to seal ducting. Low Cost.

6 Wrap the hot water tank with jacket insulation. This simple, inexpensive measure will reduce standby heat loss from the tank. Be sure to leave the air intake vent uncovered when insulating a gas water heater. Low Cost.

Replace air filters regularly and follow maintenance schedules for furnace and air-conditioning equipment. Replacing a dirty air filter can save money by reducing the amount of electricity needed to run a blower motor (because there is less resistance to airflow with a clean filter). Low Cost. 
8 Install programmable thermostats. These inexpensive devices, most incorporating modern microprocessor-based electronics, can help optimize your building's heating and cooling needs. And you won't need to remember to change thermostat settings every time you open or close your business. Low Cost

9 Install automatic room-lighting controls. Similar to programmable thermostats, these devices help optimize lighting use by automatically turning lights on or off, depending on occupancy or time of day. Sensors and timers work well and are usually installed by a specialist. Low Cost.

(10 Clean heat exchangers and perform routine maintenance on refrigerating equipment. These simple measures will ensure the most efficient operation of heat exchangers needed for cooling or refrigerating equipment. No Cost.

Seal off unused areas and don't heat or cool these areas. Storage areas represent a good place to start; turn off heating and cooling to these areas. No Cost.

(12 Turn off machines and equipment when not needed. In many businesses, this simple approach can achieve big savings. Don't underestimate the energy savings you can get by turning off unused computers, monitors, printers, and copiers. No Cost.

Buy energy-efficient equipment. When buying or replac ing computers, copiers, and other office equipment, compare energy requirements of various models. Low Cost.

(44) Seal exterior cracks and holes, and ensure tight-fitting windows. Seemingly small cracks or holes in the building exterior (like walls, windows, doors, ceiling, and floors) can really add up to substantial heating or cooling losses. Install weather stripping and caulking to stop these air leaks. Low Cost.

\section{(15 Shade sun-exposed windows and building walls.}

In most areas of the country, direct sunlight streaming through windows at the wrong time of the year can substantially increase your air-conditioning costs. During the cooling season, use shading methods (like window coverings, awnings, trees, and bushes) wherever possible. Low Cost.

\section{Repaint building exterior with light colors. When it's} time to repaint the exterior of your building, consider using light colors. More sunlight will be reflected away from the building, thus lowering air-conditioning expenses-perhaps your largest energy expense. This is especially true for your roof. Low Cost.

Keep exterior doors closed as much as possible. Don't heat or cool the outdoors. No Cost.
(18 Block and insulate unneeded windows and other openings. Aside from the important security benefit, covering unneeded windows and doors can greatly reduce energy losses from these openings. Low Cost.

Buy energy-efficient vehicles. When buying or replacing company-owned vehicles, compare energy requirements of various models. No Cost or Low Cost.

\section{Encourage employees to be energy conscious.}

The importance of getting employee cooperation shouldn't be underestimated; their practices and activities can make or break efforts such as these. Consider offering a small reward or other incentive for the employee who saves the most energy. No Cost.

This document is also available on the Internet at http://www.eren.doe.gov. Click on Energy Efficiency and Renewable Energy Clearinghouse (EREC).

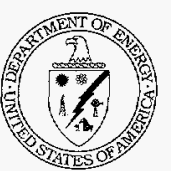

This document was produced for the U.S. Department of Energy (DOE) by the National Renewable Energy Laboratory, a DOE national laboratory. The document was produced by the Technical Information Program, under the DOE Office of Energy Efficiency and Renewable Energy. DOE/GO-10095-194 • DE95009274 • September 1995

Printed with a renewable-source ink on paper containing at leas $50 \%$ wastepaper including $20 \%$ postconsumer waste

10 To receive a free booklet listing additional ways to cut your energy expenses, please complete and return the following form.

Name

Title

Organization

Street Addres

City, State, Zip Code

Phone

Fax

E-mail

Energy Efficiency and Renewable Energy Clearinghouse

Mail: P.O. Box 3048, Merrifield, VA 22116

Phone: (800) DOE-EREC

Fax: (703) 893-0400

E-mail: energyinfo@delphi.com 


\section{DISCLAIMER}

Portions of this document may be illegible in electronic image products. Images are produced from the best available original document. 